\title{
KINERJA GURU BIMBINGAN DAN KONSELING SMP DI SUB RAYON 01 KOTA BEKASI
}

\author{
Siti Suryarsi ${ }^{1}$ \\ Dede Rahmat Hidayat ${ }^{2}$ \\ Aip Badrujaman ${ }^{3}$
}

\begin{abstract}
Abstrak
Penelitian ini bertujuan untuk mengetahui perbedaan kinerja Guru Bimbingan dan Konseling (BK) berdasarkan: Kualifikasi Akademik dan status kepegawaian. Selain itu penelitian ini juga bertujuan untuk mengetahui hubungan jumlah siswa asuh dengan kinerja Guru Bimbingan dan Konseling. Populasi dan sampel penelitian adalah semua Guru Bimbingan dan Konseling SMP di Sub Rayon 01 Kota Bekasi yang berjumlah adalah Guru Bimbingan dan Konseling sebanyak 53 orang. Teknik pengumpulan data dengan menggunakan Instrumen PKG dan dokumentasi. Data dianalisis menggunakan Mann-Whitney U-Test. hasil bahwa kinerja Guru Bimbingan dan Konseling yang Kualifikasi Akademik S1-BK memiliki kinerja yang lebih tinggi dengan Guru Bimbingan dan Konseling yang non BK. Berdasarkan status kepegawaian Guru Bimbingan dan Konseling PNS memiliki kinerja yang lebih tinggi dibandingkan dengan guru BK non PNS.

Kata Kunci: Kinerja Guru Bimbingan dan Konseling, Kualifikasi Akademik, Status Pegawai
\end{abstract}

\begin{abstract}
This study aims to determine the differentiation between performance of Guidance and Counseling teacher (BK) based on: educational background and employment status. Research method used was survey. Responden are Guidance and counseling teachers in Junior high school in Bekasi City $(N=53)$. Data collected by questionnaires and archive documentation. Data analyzed by Mann-Whitney UTest. The results showed that the performance of Guidance and Counseling teachers with educational background Guidance and Counseling is greater than Guidance and Counseling teachers with non-Guidance and Counseling education background. The results also showed that the performance of teachers Guidance and Counseling status of civil servants (PNS) greater than the performance of teachers Guidance and Counseling status non civil servants (PNS)

Keywords: Guidance and Counseling teachers, educational backgroud, civil servant, foster students, The performance of Guidance and Counseling (BK) teachers
\end{abstract}

\section{PENDAHULUAN}

Tujuan layanan bimbingan dan konseling di sekolah sesuai dengan tujuan pendidikan nasional, sebagaimana tertuang dalam Undang-undang Sistem Pendidikan Nasional No. 20 Tahun 2003, yaitu untuk

\footnotetext{
${ }^{1}$ Dinas Pendidikan Kota Bekasi, sitisuryarsi28@gmail.com

${ }^{2}$ Universitas Negeri Jakarta, dederhidayat@unj.ac.id

${ }^{3}$ Universitas Negeri Jakarta, aip.bj@unj.ac.id
} 
mengembangkan potensi peserta didik agar menjadi manusia yang beriman dan bertaqwa kepada Tuhan Yang Maha Esa, berakhlak mulia, sehat, berilmu, cakap, kreatif, mandiri, dan menjadi warga negara yang demokratis serta bertanggung jawab. Sedangkan tujuan khusus dari layanan bimbingan dan konseling adalah untuk membantu siswa agar dapat mencapai tujuan-tujuan perkembangan yang meliputi aspek pribadi, sosial, belajar dan karir. Untuk mencapai tujuan layanan BK, guru BK dituntut untuk melaksanakan tugas pokok Guru Bimbingan dan Konseling meliputi; menyusun rencana bimbingan, melaksanakan bimbingan, mengevaluasi proses dan hasil bimbingan, serta melakukan perbaikan tindak lanjut bimbingan dengan memanfaatkan hasil evaluasi. Berdasarkan Permendiknas Nomor 35 tahun 2010, hal ini dimungkinkan agar layanan bimbingan dan konseling dapat berjalan dengan baik serta siswa dapat memahami peran, fungsi dan tujuan dari pelayanan bimbingan dan konseling disekolah.

Kinerja Guru Bimbingan dan Konseling sangat mempengaruhi kualitas pendidikan, dan diharapkan Guru Bimbingan dan Konseling memiliki kerja yang baik, misalnya memiliki kemampuan memahami dan melaksanakan etika profesional, mempunyai rasa kesadaran diri mengenai kompetensi berupa nilai-nilai dan sikap, memiliki karakteristik diri, yakni respek terhadap orang lain, fleksibel dalam pandangan dan emosional stabil, dapat berkomunikasi dan berinteraksi secara efektif dan efisien dengan klien, mempunyai rasa empati yang tinggi, selalu tersenyum, mampu bekerja sama sesama guru, orang tua siswa, dan masyarakat sekitarnya.

Permasalahan rendahnya kinerja Guru Bimbingan dan Konseling di sekolah dibuktikan hasil penelitian Walantri (2009) Guru Bimbingan dan Konseling/Konselor yang berlatar belakang disiplin ilmunya S1Non BK sering kali tidak menunjukkan kinerja yang baik, hal ini terlihat dengan tidak dilaksanakan beberapa kegiatan Bimbingan dan Konseling disekolah tersebut. Terlepas dari perbedaan latar belakang pendidikan Guru Bimbingan dan Konseling di instansi sekolah, faktanya yang terjadi sekarang siswa tetap menganggap Guru Bimbingan dan Konseling sebagai guru yang ditakuti tugasnya hanya menghukum siswa saja.

Kinerja Guru Bimbingan dan Konseling dalam mendukung kegiatan belajar mengajar melalui layanan BK dan pemahaman tentang kepribadian konseli (siswa) ditulis Sulistyowati (2012) tentang problematic kinerja Konselor SMA seKabupaten Sleman hal ini tentu saja menjadi permasalahan kinerja Guru Bimbingan dan Konseling untuk mencapai layanan bimbingan disekolah secara maksimal dan akhirnya akan berdampak pada lulusan disekolah tersebut.

Hasil supervisi di sepuluh sekolah binaan ditemukan bahwa Guru Bimbingan dan Konseling rata-rata tidak menerapkan landasan teoritik tentang tehnik-tehnik konseling, terkesan ngobrol dan ada sekolah yang banyak memberi nasehat dari pada mendengarkan pembicaraan siswa. Ini tentu tidak bisa membuka tabir permasalahan siswa tersebut, diketemukan sekolah tidak mempunyai ruang konseling sendiri, atau ada tetapi tidak refresentatif, buku penunjang, aplikasi pendukung, sarana lain tidak lengkap. Hasil observasi awal di sekolah-sekolah binaan penulis di SMP Kota Bekasi menemukan, masih ada guru kualifikasi akademik S1 Non-BK ini dibuktikan data dari

kepegawaian Dinas Pendidikan Kota Bekasi Tahun 2017 diketahui bahwa persentase Guru Bimbingan dan Konseling SMP yang kualifikasi akademik S1 Non BK sebesar $33 \%$ dari jumlah 300 orang menyebar kesemua sekolah baik SMP Negeri maupun SMP Swasta dengan rincian : 1) Guru Bimbingan dan Konseling di SMP Negeri berjumlah 116 orang yang memiliki ijazah S1 BK sebanyak 106 orang dan S1 Non BK sebanyak 10 orang (10\%). 2) Guru Bimbingan dan Konseling di SMP Swasta 
sebanyak 194 orang yang memiliki ijazah S1 BK sebanyak 194 orang dan S1 Non BK sebanyak 105 orang $(45,88 \%)$. 3) Hasil wawancara Guru Bimbingan dan Konseling merasa beban kerja cukup berat rata-rata 300 Orang, melebihi jumlah rasio siswa yaitu 1 : $150 / 160$ siswa. 4) Honor yang diterima Guru Bimbingan dan Konseling Non-PNS dirasakan tidak sebanding dengan beban kerja.

Permasalahan yang lain tentang rendahnya kinerja Guru Bimbingan dan Konseling SMP di Kota Bekasi dapat dilihat berdasarkan hasil Uji Kinerja Guru Bimbingan dan Konseling (UKG BK) Tahun 2015. Diketahui bahwa nilai rata-rata kineja guru Bimbingan dan Konseling untuk kinerja pedagogik 42,65 dan kinerja profesional 73. Angka tersebut kurang baik, dan berdampak pada kinerja Guru Bimbingan dan Konseling yang kurang optimal. Karena guru harus memiliki ilmu pengetahuan bidang pendidikan, cakap dan terlatih menjadi guru, berkarakter, mampu menyesuaikan diri dengan lingkungan dan masyarakat, dan mempunyai motivasi bekerja yang tinggi sehingga dapat meningkatkan kinerjanya. Nilai UKG Guru Bimbingan dan Konseling SMP di Kota Bekasi sebagian besar (59) adalah C. hal ini sangat memprihatinkan perlu dianalisa dan mendapat perhatian khusus dari pihak Dinas Pendidikan. Karena dengan nilai yang relative rendah dapat dikatakan ada masalah berkaitan dengan kinerja Guru Bimbingan dan Konseling SMP di Kota Bekasi.

Berdasarkan hasil data dari bagian Keuangan Dinas Pendidikan Kota Bekasi dan survai kesekolah swasta penghasilan PNS dan Non PNS jauh perbedaannya. Guru PNS Golongan III/IV Penghasilan Tetap sebesar Rp 3.500.000 sampai dengan $\mathrm{Rp}$ 4.800.000, Tunjangan Daerah Rp 5.100.000, Tunjangan Profesi Rp 3.500.000, dan masih ada tunjangan lain yang tidak mengikat ( walikelas, Pembina, Wakil Kepala Sekolah dil). Guru Non PNS Golongan III/IV Penghasilan tidak menentu tergantung jumlah Jam mengajar atau Bimbingan, ratarata perjam dihargai $R p$ 50.000, tidak semua guru mendapat tambahan tunjangan Profesi. Guru PNS pada umumnya sering mendapat kesempatan dalam pengembangan keprofesian berbentuk worshop, IHT dll, perbedaan penghasilan serta sarana maupun fasilitas antara guru PNS dan Non PNS dapat berpengaruh terhadap kinerja guru tersebut. Dari pemaparan diatas dapat penulis simpulkan bahwa terdapat beberapa permasalahan dalam pelaksanaan layanan bimbingan belajar, yakni masalah Kualifikasi Akademik Guru Bimbingan dan Konseling., perbedaan penghasilan dan fasilitas bagi guru PNS dan Non PNS, Jumlah siswa yang menjadi beban kerja layanan yang berakibat pada pelaksanaan kegiatan layanan konseling tidak merata, lebih banyak berfungsi dalam pengentasan masalah (kuratif), guru pembimbing aktif ketika terjadi permasalahan pada siswa, kurangnya kreativitas guru pembimbing dalam memberikan model atau tehnik layanan yang tepat.

Berdasarkan pemaparan di atas maka peneliti memandang perlu diadakan suatu penelitian lebih lanjut terkait dengan kinerja Guru Bimbingan dan Konseling di SMP Sub Rayon 01 Kota Bekasi. Pertanyaan penelitian yang ingin dijawab adalah

1. Bagiamana gambaran Kinerja Guru Bimbingan dan Konseling SMP di Sub Rayon 01 Kota Bekasi

2. Apakah ada perbedaan kinerja Guru Bimbingan dan Konseling SMP di Sub Rayon 01 Kota Bekasi yang kualifikasi Akademik S1-BK dan S1-Non BK

3. Apakah ada perbedaan kinerja Guru Bimbingan dan Konseling SMP di Sub Rayon 01 Kota Bekasi yang berlatar belakang PNS dan Non PNS

Kinerja (performance) sering diartikan sebagai prestasi, efektif kerja, hasil nyata kerja untuk meraih tujuan, produktifitas dalam proses bekerja, seperti yang diungkapkan Sinambela (2012) bahwa kinerja pegawai sebagai kemampuan dalam melakukan sesuatu keahlian tertentu. Ungkapan yang sama disampaikan oleh 
Mangkunegara (2015) Kinerja (prestasi kerja) adalah hasil kerja secara kualitas dan kuantitas yang dicapai oleh seorang pegawai dalam melaksanakan tugas sesuai dengan tanggungjawab yang diberikan kepadanya. Kinerja sebagai kemampuan seseorang untuk mengerjakan sesuatu dengan segenap kemampuannya. Robin (2003) mengemukakan kinerja adalah hasil evaluasi pekerjaan yang dilakukan sesorang dibandingkan dengan kriteria yang telah ditetapkan. Artinya bahwa kinerja seseorang harus ditunjukan tingkat keberhasilan yang sudah dicapai, untuk mengukur seberapa jauh pencapaian dalam melaksanakan tugas

Menurut Bernardin dan Russel dalam Suharsaputra (2010) kinerja sebagai hasil akhir yang didapat pada diri seseorang baik berbentuk jabatan atau kegiatan selama periode yang telah ditetapkan oleh perusahan atau instansi tersebut. Berdasarkan pendapat ahli, pengertian kinerja merupakan unjuk kerja atau kemampuan pegawai dalam melaksanakan tugas dan tanggung jawabnya, serta dapat pencapaian hasil yang memuaskan, keberhasilan itu akan memotivasi seorang pegawai untuk terus meningkatkan kemampuan dan ketrampilan dalam tugas sehari-hari dengan harapan mendapatkan penghargaan yang lebih dari apa yang sudah dikerjakan.

\section{Dimensi / Aspek Kinerja}

Mengacu pada konsep kinerja atau teori yang telah diuraikan di atas terlihat bahwa kinerja selalu berbicara tentang proses dan hasil akhir, sementara itu dalam kinerja perlu dipahami juga tentang dimensi kinerja atau kriteria kinerja dan elemen dalam pekerjaan yang dianggap memiliki andil dalam keberhasilan pelaksanaan pekerjaan tersebut secara keseluruhan. Dengan mengetahui dimensi kinerja dari suatu pekerjaan, kita bisa mengembangkan standar-standar untuk mempermudah proses penilaian kinerja, ada tiga dimensi kinerja yaitu: Kemampuan, motivasi dan peluang yang didapat digambarkan seperti pada gambar 1.

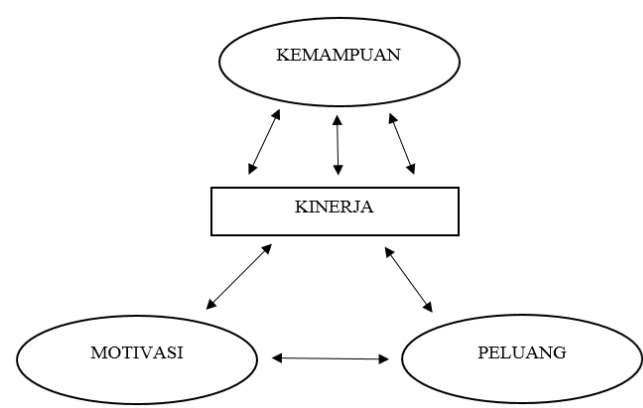

Gambar 1. Hubungan antara Kemampuan, motivasi dan peluang

Gambar tersebut menunjukkan bahwa kinerja memiliki tiga dimensi yaitu kemampuan, motivasi dan peluang. ketiga dimensi tersebut saling terkait dan saling berhubungan satu dengan yang lain. Selanjutnya Gibson (1996) mengemukakan bahwa kinerja individu dipengaruhi oleh enam faktor yaitu: motivasi atau keinginan, bakat, minat dan kemampuan, kesempatan (peluang) meningkatkan karier, keiklasan menjalankan tugas, kepuasan kerja, imbalan terhadap prestasi

Faktor kesempatan untuk dukungan organisasi (organization support) yaitu perangkat sarana dan prasarana, lingkungan kerja, sistem imbalan dan pengembangan karier bagi pegawai termasuk dalam dimensi untuk mendorong ketercapaian kinerja pegawai dalam melaksanakan tugasnya sehari-hari. Setiap anggota dari kelompok yang bekerja harus mendukung dan melaksanakan tugas sesuai dengan tata kelola dan aturan yang dipakai dalam bekerja. Dimensi kinerja dari instansi dimana seorang bekerja perlu menjadi sorotan bagi pimpinan di mana seseorang bekerja agar timbul semangat dan motivasi kerja dari diri seorang pegawai. Selain itu aspek-aspek kinerja untuk mengukur ketercapaian kinerja seorang pegawai harus diperhatikan.

\section{Kinerja Guru Bimbingan dan Konseling/Konselor}

Kinerja Guru Bimbingan dan Konseling adalah pelaksanaan tugas sebagai guru pembimbing. Dalam Surat Keputusan Bersama Kemendikbud dan Kepala BAKN 
No.0433/P/1993 dan No. 25 Tahun 1993 tentang Petunjuk Pelaksanaan Jabatan Fungsional Guru dan Angka Kriditnya pasal 1 , ayat 11 sampai 14 menyebutkan bahwa Guru Pembimbing adalah guru yang mempunyai tugas, tanggung jawab, wewenang, dan hak secara penuh dalam kegiatan bimbingan dan konseling terhadap jumlah peserta didik.

Tugas pokok Guru Bimbingan dan Konseling terdapat unsur utama yaitu: (1) Bidang- bidang bimbingan(bimbingan pribadi, sosial, belajar, dan karier), (2) jenisjenis layanan (orientasi, informasi, penempatan dan penyaluran, konseling individu, bimbingan kelompok, konseling kelompok), (3) jenis-jenis pendukung bimbingan dan konseling (aplkasi instrumentasi, himpunan data, konferensi kasus, kunjungan rumah, alih tangan kasus), (4) jumlah peserta didik yang menjadi siswa asuhnya. Sejalan dengan adanya perubahan Kurikulum dipaparkan bahwa tugas Guru Bimbingan dan Konseling adalah: memasyarakatkan pelayanan bimbingan dan konseling, merencanakan program, melaksanakan program layanan bimbingan dan konseling, melaksanakan segenap program kegiatan pendukung, Menialai proses dan hasil pelasanaan kegiatan bimbingan dan konseling menganalisa hasil penilaian layanan dan kegiatan bimbingan dan konseling, melaksanakan tindak lanjut berdasarkan hasil penilaian layanan dan bimbingan dan konseling, mengadministrasikan kegiatan satuan layanan dan kegiatan pendukung bimbingan dan konseling, mempertanggungjawabkan tugas dan kegiatan dalam pelayanan bimbingan dan konseling secara menyeluruh kepada koordinator BK serta kepala sekolah, mempersiapkan diri, menerima dan partisipasi aktif dalam kegiatan kepengawasan oleh Pengawas Sekolah bidang Bimbingan dan Konseling, Berpartisi aktif dalam kegiatan MGBK

Keberhasilan program kerja Guru Bimbingan dan Konseling sangat tergantung pada kinerja Konselor disekolah, dalam memandirikan konseli, seperti pendapat
Corey (2010) seorang Konselor mampu bertindak dalam bingkai filosofik yang akan membentuk suatu wawasan (worldview), yang mewarnai diri konseli untuk melihat dunianya, maka Guru Bimbingan dan Konseling harus profesional dengan tugas dan kewajiban; merencanakan, melaksanakan, melakuakan penilaian dan evaluasi, melakukan tindak lanjut hasil evaluasi dan mampu membuat laporan hasil kerja bimbingan dan konseling disekolah. $\mathrm{Hal}$ ini didukung oleh Permenneg PAN dan RB No, 16 Tahun 2009 BAB I, Pasal 1 ayat 4. dan mekanisme penilaian kinerja guru diperlukan untuk mengevaluasi tingkat keberhasilan kerja guru terhadap pelaksanaan tugas dan kewajibannya yang diakibatkan oleh kinerjanya.

Pelaksanaan tugas utama guru tidak dapat dipisahkan dari kemampuan seorang guru dalam penguasaan dan penerapan kompetensinya. Dalam hal ini adalah kompetensi yang sangat diperlukan bagi guru seperti yang diamanatkan oleh Peraturan Menteri Pendidikan Nasional Nomor 16 Tahun 2007 tentang Standar Kualifikasi Akademik dan Kompetensi Guru. Penguasaan dan penerapan kompetensi sangat menentukan tercapainya kualitas proses pembelajaran, pembinaan peserta didik, dan pelaksanaan tugas tambahan yang relevan yang sesuai denga fungsi sekolah/madrasah. Untuk itu, perlu dikembangkan sistem penilaian kinerja guru.

Penilaian Kinerja Guru adalah penilaian tentang butir-butir kegiatan tugas yang telah dikerjakan baik itu tugas utama, tugas tambahan lainnya, diukur menggukan pedoman atau aturan penilaian yang sudah ditetapkan dengan tujuan untuk mengetahui sejauh mana keberhasilan dari tugas dan tanggung jawab dalam rangka pembinaan karier kepangkatan dan jabatannya. hal ini tercantum dalam Permen PAN dan RB No, 16 Tahun 2009 BAB I, Pasal 1 ayat 8. Penilaian Kinerja bagi Guru Bimbingan dan Konseling menurut Buku Pedoman Pelaksanaan Penilaian Kinerja Guru (2012) meliputi kegiatan merencanakan dan 
melaksanakan pembimbingan, mengevaluasi dan menilai hasil bimbingan, menganalisis hasil evaluasi pembimbingan dan melaksanakan tindak lanjut hasil pembimbingan. Berdasarkan Peraturan Menteri Pendidikan Nasional Nomor 27 Tahun 2008 tentang Standar Kualifikasi Akademik dan Kompetensi Konselor terdapat 4 (empat) ranah kompetensi yang harus dimiliki oleh guru BK/Konselor. Penilaian kinerja guru $\mathrm{BK} /$ konselor mengacu pada 4 domain kompetensi tersebut yang mencakup 17 (tujuh belas) kompetensi dan 70 Indikator.

Uraian tentang Dimensi tugas dan Indikator kinerja Guru Bimbingan dan Konseling dapat diuraikan sebagai berikut: 1)Perencanaan kegiatan layanan meliputi: menguasai teori dan praktis pendidikan, menghargai dan menjunjung tinggi nilainilai kemanusiaan, individualitas dan kebebasan memilih, merancang program BK. 2) Pelaksanaan kegiatan layanan meliputi: Mengaplikasikan perkembangan fisiologi dan psikologis serta perilaku konseling pengembangannya, menguasai esensi pelayanan bimbingan dan konseling jalur, jenis dan jenjang satuan pendidikan, beriman dan bertakwa kepada Tuhan Yang Maha Esa, menunjukkan integritas dan stabilitas kepribadian yang kuat, menampilkan kinerja berkualitas tinggi, mengimplementasikan kolaborasi internal di tempat bekerja, berperan dalam organisasi dan kegiatan profesi BK, mengimplementasikan kolaborasi antarprofesi, menguasai kerangka teoretik dan praksis $\mathrm{BK}$, mengimplementasikan program BK yang komprehensif, memiliki kesadaran dan komitmen terhadap etika professional. 3.Evaluasi dan Penilaian serta laporan hasil Tindak Lanjut kegiatan layanan meliputi: menguasai konsep dan praksis penilaian (assesment) untuk memahami kondisi, kebutuhan, dan maslah konseli, menilai proses dan hasil kegiatan BK, menguasai konsep dan praksis penelitian dalam BK, disusun berdasarkan indikator yang dari konsep kinerja Guru Bimbingan dan Konseling.

\section{Kinerja Guru Bimbingan dan Konseling yang mempunyai kualifikasi S1 -BK dan S1- Non BK}

Guru wajib memiliki kualifikasi Akademik, kompeten dalam bidangnya, mempunyai sertifikat sebagai guru profesional dan sehat lahir dan bathin agar terwujudkan tujuan Pendidikan Nasional, sesuai dengan UU RI No:14 Tahun 2005 pasal 8, begitu juga untuk Guru Bimbingan dan Konseling atau disebut juga Konselor adalah tenaga pendidik profesional yang telah menyelesaikan pendidikan akademik strata satu (S-1) program studi bimbingan dan konseling dan program pendidikan profesi Konselor dari perguruan tinggi penyelenggara program pengadaan tenaga kependidikan yang terakreditasi. .

Kualifikasi akademik Konselor yang dimaksut yaitu jalur pendidikan yang ditempuh disalah satu Universitas dan lulus mendapat ijazah sarjana pendidikan (S-1 dan D-IV) dalam bidang bimbingan dan konseling serta mengikuti pendidikan profesi Konselor sekolah, kompeten seorang Guru Bimbingan dan Konseling dalam bidang akademik mencakup bidang: Penguasaan keilmuan BK baik teori maupun praktik, penguasaan dasar dan hakikat BK dipandang dari berbagai macam mulai pembuatan program kegiatan, tujuan, asas, kegunaan. visi / misi dan lainnya serta mampu menganalisa faktor penyebab terhambatnya prroses BK, dibuat itindak lanjut keprogram BK selanjutnya, mengaplikasikan perkembangan perubahan dan kemajuan ilmu pengetahuan tentang perilaku dan fungi manusia terhadap proses kehidupan masa depan. Berdasarkan uraian di atas diartikan kualifikasi akademik Guru

Bimbingan dan Konseling atau Konselor adalah ketercapaian dalam pendidikan formal dan mendapat ijazah sarjana (S-1/ D-IV) program studi bimbingan dan konseling dan mengikuti program pendidikan profesi Konselor, serta lulus dalam uji sertfikasi Guru Bimbingan dan Konseling. mempunyai hak dan 
tanggung jawab juga wewenang dalam kegiatan bimbingan konseling terhadap sejumlah siswa disekolah.

Penelitian yang mendukung dari pernyataan tersebut analisis dari penelitian Ermelinda dkk, dapat disimpulkan bahwa terdapat hubungan yang positif dan signifikan antara kualifikasi akademik dengan kinerja guru melalui persamaan regresi $\hat{\mathrm{Y}}=129,615+5,797 \mathrm{X} 1$ dengan kontribusi sebesar $22,0 \%$ dan sumbangan efektifnya sebesar $12,1 \%$. Dengan demikian dapat dikatakan bahwa apabila skor pencapaian kualifikasi akademik ditingkatkan sampai dengan skor 5 (skor tertinggi) maka kinerja guru meningkat dari 152,154 menjadi 158,6. Dengan kata lain semakin baik kualifikasi akademik guru makin baik pula kinerja guru.

\section{Kinerja Guru Bimbingan dan Konseling yang berstatus PNS dan Non PNS}

Profesi guru memberikan kesempatan bagi seseorang untuk mewujudkan hal-hal baik dalam kehidupannya, sehingga seseorang yang telah memilih profesi guru sebagai jalan hidupnya dapat melaksanakan tugasnya dengan penuh tanggung jawab. Guru memaknai setiap peristiwa dalam kehidupannya dengan mengarahkan perasaannya pada hal-hal yang positif. Bagi guru PNS diharapkan dapat selalu berbahagia dan mengajar disertai dengan hati yang tulus agar anak didik dapat menerima pelajaran dengan baik.

Status guru apakah PNS atau non PNS akan berdampak teradap pendapatan yang diperoleh. Guru PNS lebih diminati karena kesejahteraaanya lebih terjamin dan relative aman serta nyaman. Kondisi seperti ini akan berpengaruh terhadap prestasi kerjanya. Guru berstatus PNS akan lebih focus dalam bekerja karena telah mendapat jaminaan kesejahteraan dari Pemerintah. Sementara guru honorer tidak sebanding dengan upah guru PNS, apakah hal ini mempengaruhi hasil kinerja guru honorer? jika dilihat secara tugas dan tanggung jawab seharusnya tidak ada perbedaan. Namun berdasarkan motivasi kinerja guru PNS dan Honorer terdapat perbedaan hal ini di sampaikan dalam penelitian Wahyuningsih (2011) bahwa terdapat perbedaan yang signifikan motivasi guru PNS dan guru non PNS di SD Negeri se UPT Dinas Pendidikan kecamatan Nguter Sukoharjo dilihat dari kepemimpinan, dan rata-rata motivasi kerja guru PNS lebih tinggi dibandingkan dengan guru non PNS. Berdasarkan uraian tersebut maka hipotesis yang diajukaan adalah:

H1 : Ada perbedaan antara kinerja Guru Bimbingan dan Konseling yang kualifikasi S1 dari program studi bimbingan dan Konseling dibandingkan dengan kinerja Guru Bimbingan dan Konseling yang non Bimbingan dan Konseling.

H2 : Ada perbedaan antara kinerja Guru Bimbingan dan Konseling yang berstatus PNS dengan kinerja Guru Bimbingan dan Konseling yang berstatus non PNS.

\section{METODE PENELITIAN}

Metode penelitian yang penulis lakukan menggunakan survey menggunakan analisis komparatif dengan Mann-Whitney U-Test. Penelitian komparatif adalah penelitian ynag bersifat membandingkan persamaan dan perbedaan dua atau lebih fakta-fakta dan sifat-sifat objek yang diteliti berdasarkan kerangka pemikiran.

\section{Populasi dan Teknik Pengambilan Sampel}

Populasi penelitian ini adalah semua guru Bimbingan Konseling di Sub Rayon 01 Kota Bekasi yang berjumlah 53 Orang. Karena jumlah populasi yang ada kurang dari 100 maka populasi dijadikan sebagai sampel. Target populasi penelitian ini adalah semua Guru Bimbingan dan Konseling SMP di Sub Rayon I Kota Bekasi. Berdasarkan data yang didapat dari Dinas Pendidikan kota Bekasi, ada 46 sekolah dan jumlah Guru Bimbingan dan

Konseling 53 orang. Sedangkan sampelnya adalah semua Guru Bimbingan 
dan Konseling SMP di kota Bekasi Rayon I, dengan demikian teknik pengambilan sampel adalah sensus dan jumlah sampel sebanyak jumlah populasinya yaitu 53 responden.

\section{Instrumen Penelitian}

Instrumen penelitian yang digunakan adalah Instrumen Penilaian Kinerja Guru Bimbingan dan Konseling yang digunakan oleh Pengawas Pembina SMP di Sub Rayon 01 Kota Bekasi untuk mengukur kinerja guru BK.

Instrumen Penilaian Kinerja Guru Bimbingan dan Konseling terdiri dari 17 indikator Kinerja Guru Bimbingan dan Konseling dilengkapi dengan 70 butir pertanyaan, dasar hukum Penilaian Kinerja Guru Bimbingan dan Konseling (PKG BK) yaitu Permenneg PAN dan RB No, 16 Tahun 2009. Disebutkan agar dapat melaksanakan tugas dan kewajibannya, guru yang profesional harus memiliki penguasaan terhadap sejumlah kinerja yaitu pedagogik, profesional, sosial dan kepribadian dan berdasarkan Peraturan Menteri Pendidikan Nasional Nomor 16 Tahun 2007. mekanisme penilaian kinerja guru diperlukan untuk mengevaluasi unjuk kerja guru terhadap pelaksanaan tugas dan kewajibannya dalam Perencanaan Layanan BK, Pelaksanaan Layanan BK dan Evaluasi pelaporan dan tindak lanjut layanan BK dan Buku Panduan Penilaian Kinerja Guru (2012)

\section{Teknik Analisis Data}

Penelitian ini akan menggunakan teknik analisis deskriptif dan inferensial. Analisis deskriptif untuk menggambarkan semua data dari variabel penelitian dalam bentuk tabel, sedangkan analisis inferensial digunakan untuk menguji hipotesis perbedaan. Teknik pengujian hipotesis yang dipergunakan adalah: uji Mann Whitney U Test karena distribusi tidak normal.

\section{HASIL PENELITIAN Profil Responden}

Profil Responden Guru Bimbingan dan Konseling SMP di Sub Rayon 01 Kota Bekasi sebagai berikut:

1. Kualifikasi akademik

Guru BK yang kualifikasi S1 BK sebanyak 39 orang dan Guru BK yang kualifikasi Non BK sebanyak 14 orang

2. Status Kepegawaian

Guru BK PNS sebanyak 21 orang dan Guru BK Non PNS sebanyak 32 Orang. Sehingga jumlah adalah sebanyak 53 orang

Berdasarkan hasil penelitian, deskripsi Kinerja Guru Bimbingan dan Konseling SMP di Sub Rayon 01 sercara individual dapat ditunjukkan pada klasifikasi berikut ini

\section{Deskripsi}

Hasil klasifikasi kinerja Guru Bimbingan dan Konseling SMP Sub Rayon 01 Kota Bekasi: 22 orang Baik (B), 16 orang cukup baik (C), 5 orang sedang (D) dan 10 orang kurang baik (E). Kalau di buat rata rata secara keseluruhan maka kinerja Guru Bimbingan dan Konseling kota Bekasi menunjukkan posisi Cukup

\begin{tabular}{clc}
\hline NO & \multicolumn{1}{c}{ DIMENSI } & RERATA \\
\hline 1 & $\begin{array}{l}\text { Persiapan Kegiatan Layanan } \\
2\end{array}$ & $\begin{array}{l}\mathbf{7 4 . 5 5} \\
\text { Pelaksanaan Kegiatan }\end{array}$ \\
$\begin{array}{l}\text { Layanan } \\
3\end{array}$ & $\begin{array}{l}\mathbf{7 4 . 3 0} \\
\text { Evaluasi dan Penilaian serta } \\
\text { laporan hasil tindak lanjut }\end{array}$ & $\mathbf{4 5 . 0 7}$ \\
\multicolumn{2}{l}{ Rata-rata } & $\mathbf{6 4 , 6 4}$ \\
\hline
\end{tabular}

Tabel 1. Dimensi Tugas Guru Bimbingan dan Konseling SMP

Hasil perolehan dari dimensi tugas Guru Bimbingan dan Konseling meliputi : Persiapan Kegiatan Layanan, Pelaksanaan Kegiatan Layanan dan Evaluasi Penilaian serta laporan hasil tindak lanjut. Dapat dilihat di tabel 2.

Berdasarkan tabel tersebut pencapaian dimensi tugas Guru Bimbingan dan Konseling SMP Sub Rayon 01 Kota Bekasi sebagai berikut:

a. Pencapaian Persiapan kegiatan Layanan sebesar 74.55 
b. Pencapaian Pelaksanaan Kegiatan Layanan sebesar 74.30

c. Pencapaian Evaluasi dan Penilaian Layanan swbesar 45.07

d. Rerata hasil 64.64

\section{Kerja Guru Bimbingan dan Konseling Yang Kualifikasi Akademik S1-BK dan S1- Non BK}

Untuk mengetahui perbedaan kinerja Guru Bimbingan dan Konseling berdasarkan latar belakan S1 BK dan S1 non BK dilakukan pemngolahan data dengan menggunakan teknik analisis MannWithney Test. Output satatistik dapat dilihat pada Tabel 3 di bawah ini

\begin{tabular}{lcc}
\hline \multicolumn{1}{c}{ Kualifikasi Akademik } & N & Rerata \\
\hline $\begin{array}{l}\text { Kinerja Guru } \\
\text { Bimbingan } \\
\text { dan Konseling }\end{array}$ & 39 & 32.85 \\
$\begin{array}{l}\text { S1/ BK } \\
\text { S1/ NON BK }\end{array}$ & 14 & 10.71 \\
Jumlah & 53 & \\
\hline
\end{tabular}

Tabel 2. Hasil Output Deskriptif

\begin{tabular}{lc}
\hline & $\begin{array}{c}\text { Kinerja Guru } \\
\text { Bimbingan dan } \\
\text { Konseling }\end{array}$ \\
\hline Mann-Whitney U & 45.000 \\
Wilcoxon W & 150.000 \\
$Z$ & -4.603 \\
Asymp. Sig. (1-tailed) & .000 \\
\hline a. Grouping Variable: kualifikasi akademik \\
\multicolumn{2}{c}{ Tabel 3. Hasil Output Uji Komperatif }
\end{tabular}

Berdasarkan output di atas, dapat dijelaskan bahwa nilai mean untuk kinerja Guru Bimbingan dan Konseling SMP di kota Bekasi yang lulusan BK lebih besar daripada Guru Bimbingan dan Konseling yang lulusan non BK (32.85 lebih besar 10.71). Hasil uji Mann- Whitney, dapat dilihat pada output test statistik, menunnjukkan nilai statistik uji $\mathrm{Z}$ yang besar yaitu -4.603 dan nilai signifikan ( 1 tailed) adalah 000 lebih kecil dari 0.050 , sehingga dapat disimpulkan bahwa ada perbedaan yang signifikan antara kinerja Guru Bimbingan dan Konseling yang berlatar belakang lulusan BK dengan Guru Bimbingan dan Konseling yang berlatar belakang lulusan non BK.

\section{Penilaian Kinerja Guru Bimbingan dan Konseling yang Kualifikasi Akademik S1 BK dan Non BK.}

Penilaian Kinerja Guru Bimbangan dan Konseling SMP di Sub Rayon 01 Kota Bekasi yang dilakukan oleh: Pengawas, Kepala Sekolah dan Siswa, di dapat perolehan nilai sebagai berikut

1. S1-BK yang kinerjanya

1) Amat Baik( 0 orang) atau $0 \%$

2) Baik (21), atau $61.8 \%$

3) Cukup (10), atau $29.4 \%$

4) Sedang (3), atau $8.8 \%$

5) Kurang (0), atau $0 \%$.

Rerata kinerja Guru Bimbingan dan Konseling kualisifikasi Akademik Baik (B)

2. S1- Non Bk yang kinerjanya

1) Amat Baik 0 orang, atau $0 \%$

2) Baik 1 orang, atau $5.3 \%$

3) Cukup 6 orang, atau $31.6 \%$

4) Sedang 2 Orang, atau $10.5 \%$

5) Kurang 10 orang, atau $52.6 \%$

Rerata Kinerja Guru Bimbingan dan Konseling Sedang ( D)

Guru Bimbingan dan Konseling yang memiliki kualifikasi akademik sesuai dengan bidang yang diampunya tentu dapat menjalankan kinerjanya dengan baik, penelitian yang penul dilakukan tentang kinerja Guru Bimbingan dan Konseling mempunyai kualifikasi akademik S1-BK rata-rata kinerjananya Baik dibanding S1Non BK, hal ini membuktikan bahwa profesi guru dalam menjalankan tugasnya sebagai seorang pendidik yang profesional salah satu yang harus terpenuhi yaitu linieritas kualifikasi akademik dengan bidang study yang dikerjakan

Berdasarkan hasil penelitian yang penulis lakukan tampak jelas hasil dari 
output pengujian hipotesis, bahwa nilai mean untuk kinerja Guru Bimbingan dan Konseling SMP di kota Bekasi yang lulusan BK lebih besar daripada Guru Bimbingan dan Konseling yang lulusan non BK (32.85 lebih besar 10.71). Hasil uji Mann-Whitney, menunnjukkan nilai statistik uji $\mathrm{Z}$ yang besar yaitu -4.603 dan nilai signifikan ( 1 tailed) adalah 000 lebih kecil dari 0.050 , sehingga dapat disimpulkan bahwa ada perbedaan yang signifikan antara kinerja Guru Bimbingan dan Konseling yang kualifikasi akademik S1- BK dengan Guru Bimbingan dan Konseling yang kualifikasi akademik S1- Non BK.

Penelitian Ermelinda Yosefa et all tentang Hubungan Antara Kualifikasi Akademik, Motifasi Kerja dengan Kinerja Guru SD Di Kecamatan Bajawa (2014) menyebutkan Hasil penelitian menunjukkan bahwa; terdapat hubungan yang positif dan signifikan antara kualifikasi akademik dengan kinerja guru, terdapat hubungan yang positif dan signifikan secara bersama sama antara kualifikasi akademik, kinerja, motivasi kerja dengan kinerja guru.

Rini Purwaningsih dalam penelitiannya tentang Pengaruh Kualifikasi Akademik Terhadap Kinerja Guru SD Dabin I Kecamatan Pituruh Purworejo (2015) disampaikan berdasarkan hasil uji hipotesis diketahui terdapat pengaruh yang signifikan antara kualifikasi akademik terhadap kinerja guru SD Dabin I dan IV Kecamatan Pituruh Kabupaten Purworejo tahun pelajaran 2014/2015. Hal ini dapat dilihat berdasarkan hasil nilai $\mathrm{t}$ hitung $>\mathrm{t}$ tabel. Diketahui $\mathrm{t}$ hitung sebesar 3,283 dan nilai t tabel 1,987 karena 3,283 > 1,987 maka Ho ditolak dan $\mathrm{Ha}$ diterima artinya secara hubungan kualifikasi akademik berpengaruh terhadap kinerja guru. Sedangkan kontribusi variabel $\mathrm{X}$ terhadap variabel $\mathrm{Y}$ sebesar $10,7 \%$, kemudian sisanya $89,3 \%$ ditentukan oleh faktor-faktor lain.

\section{Kinerja Guru Bimbingan dan Konseling Yang Berstatus PNS dan Non PNS}

Untuk mengetahui kinerja Guru Bimbingan dan Konseling Yang berlatar Belakang PNS dan non PNS dapat dijelaskan seperti pada Tabel 5 dan Tabel 6 di bawah ini :

\begin{tabular}{lcc}
\hline Status pegawai & N & Rerata \\
\hline Kinerja Guru & & \\
Bimbingan dan & \\
Konseling & & \\
$\quad$ PNS & 21 & 40.36 \\
$\quad$ NON PNS & 32 & 18.23 \\
$\quad$ Jumlah & 53 \\
\hline \multicolumn{2}{c}{ Tabel 4. Hasil Output Deskriptif } \\
\multicolumn{3}{c}{ Kinerja Guru } \\
\multicolumn{3}{c}{ Bimbingan } \\
Mann-Whitney U & dan Konseling \\
Wilcoxon W & 55.500 \\
Z & 583.500 \\
Asymp. Sig. (1- & -5.105 \\
tailed) & 0.000 \\
\hline
\end{tabular}

a. Grouping Variable: status pegawai Tabel 5. Hasil Output Uji Komperatif

Berdasarkan output di atas, dapat dijelaskan bahwa nilai mean untuk kinerja Guru Bimbingan dan Konseling SMP di kota Bekasi yang berstatus kepegawaian PNS lebih besar daripada Guru Bimbingan dan Konseling yang berstatus non PNS (40.36 lebih besar 18.23).

\section{Kinerja Guru Bimbingan dan Konseling PNS dan Non PNS,}

Penelitian yang dilakukan dapat digambarkan bahwa nilai Guru Bimbingan dan Konseling berdasarkan status kepegawaian PNS sebagai berikut:

1. Guru Bimbingan dan Konseling PNS yang kinerjanya:

1) Amat Baik (0)orang, atau $0 \%$

2) Baik (18) orang, atau $33.9 \%$

3) Cukup ( 2) orang, atau $9.5 \%$

4) Sedang (0) orang, atau $0 \%$

5) Kurang (1) orang. Atau $4.8 \%$ 
Rerata Kinerja Guru Bimbingan dan Konselin berdasarkan Status PNS Baik (B)

2. Guru Bimbingan dan Konseling Non PNS yang kinerjanya:

1) Amat Baik (0 orang), atau $0 \%$

2) Baik (4)orang, atau

3) Cukup (14)orang, atau

4) Sedang (5) orang. atau

5) Kurang (9)orang, atau

$28.1 \%$.

Rerata Kinerja Guru Bimbingan dan Konseling Status Non PNS Cukup (C)

Hasil penelitian ini menunjukkan bahwa kinerja Guru Bimbingan dan Konseling PNS lebih baik daripada Guru Bimbingan dan Konseling berstatus Non PNS, hal ini dapat dimaklumi bahwa guru PNS mendapatkan kesejahteraanya lebih terjamin daripada guru non PNS, karena guru PNS ada kepastian kompensasi dari Pemerinatah, sedangkan guru non PNS kesejahteraanya tidak ada jaminan dari Pemerintah. Kondisi semacam ini akan berdampak terhadaap kinerja guru non PNS.

Dari hasil analisis penelitian didapat output nilai mean untuk kinerja Guru Bimbingan dan Konseling SMP di Sub Rayon 01 Kota Bekasi yang berstatus kepegawaian PNS lebih besar daripada Guru Bimbingan dan Konseling yang berstatus non PNS (40.36 lebih besar 18.23). Hasil uji Mann-Whitney, dapat dilihat pada output test statistik, menunnjukkan nilai statistik uji $\mathrm{Z}$ yang besar kecil yaitu -5.105 dan nilai signifikan ( 1 tailed) adalah 000 lebih kecil dari 0.050 , sehingga dapat disimpulkan bahwa ada perbedaan yang signifikan antara kinerja Guru Bimbingan dan Konseling yang berstatus kepegawaian PNS dengan Guru Bimbingan dan Konseling yang bersatus kepegawaian non PNS.

\section{Pembahasan Temuan Penelitian}

Penilaian Kinerja Guru Bimbingan dan Konseling oleh pengawas rata rata Guru Bimbingan dan Konseling SMP Sub Rayon 01 Kota Bekasi menunjukkan pada posisi Cukup (nilai 63.48)
Temuan peneliti sejalan dengan hasil penelitian yang Murni (2015) tentang Analisis Pengembangan Keprofesian Berkelanjutan Guru SMK Muhamadiyah 3 Gemolong Sragen didapatkan sekitar 70- 75 persen guru sertifikasi yang membuat administrasi guru lengkap pada awal semester. Sedangkan 30 persen lainnya membuat tetapi belum lengkap dan membuat setelah mendapat pengarahan dan tekanan dari atasan. pengembangan keprofesian berkelanjutan sebagai upaya yang ditempuh dengan cara pengembangan diri, penulisan karya ilmiah, dan karya inovatif. Upaya pengembangan diri dapat dilakukan melalui MGMP, diklat, pelatihan workshop, seminar dan sebagainya.

Penelitian yang lain yang dilakukan oleh Endang Wuryandini tentang Analisis Permasalahan dan Kebutuhan Pengembangan Keprofesian Berkelanjutan Guru SMK Bidang Keahlian Bisnis dan Manajemen Pascasertifikasi di Kota Semarang (2014) disampaikan Kegiatan PKB meliputi pengembangan diri, publikasi ilmiah, dan karya inovatif pada Guru SMK Bidang Keahlian Bisnis dan Manajemen merupakan upaya meningkatkan profesionalitas Guru agar dapat menghasilkan SDM berkualitas. Hal ini dapat ter wujud apabila guru dapat melaksanakan pembelajaran berbasis teaching factory dan melaksanakan evaluasi belajar berdasarkan kinerja (Competency Based Assesment). Kinerja guru dalam melaksanakan teaching factory dan competency based assesment) dapat dikembangkan melalui kegiatan PKB.

Hasil Penelitian Ardella dan Zaili (2012) tentang Analisis Perbandingan Kinerja Guru Pegawai Negeri Sipil dengan Guru Pengawai Swasta di Kabupaten Rokan Hulu (Studi Kasus di SMP Negeri 1 Rambah dengan SMP Muhammadiyah Rambah) dikatakan Kinerja guru PNS lebih baik dibanding dengan kinerja guru Pegawai Negeri Sipil di SMP Negeri 1 Rambah dengan SMP Muhammadiyah Rambah Kabupaten Rokan Hulu di dalam melaksanakan tugas guru. 
Peningkatan kesejahteraan seorang guru pemerintah terus berupaya untuk ditingkatkan terutama tenaga honor atau Non PNS, ini dapat dibuktikan dengan adanya tunjangan profesi baik untuk guru negeri maupun swasta dengan harapan kinerjanya akan meningkat, sehingga tidak terjadi perbedaan kinerja baik guru PNS maupun Honorer/ Non PNS. Peraturan Pemerintah Nomor 41 Tahun 2009 mendefinisikan Tunjangan profesi adalah tunjangan yang diberikan kepada guru dan dosen yang memiliki sertifikat pendidik sebagai penghargaan atas profesionalitasnya. Sesuai Pasal 15 ayat (1) PP Nomor 74 Tahun 2008. Jadi tidak ada perbedaan tunjanagan profesi antara guru berstatus PNS dan Guru Non PNS

Di daerah lain ada kinerja seorang guru berstatus PNS dan Non PNS tidak ada perbedaan. Hal ini didasari karena motivasi kerja yang tinggi dan kemauan serta kemampuan terus menerus ditingkatkan atau ada kemungkinan guru justru rendah motivasi kerjanya baik guru pns maupun non pns, sehingga rata-rata hasil penilaian kinerja guru tersebut sedang atau kurang. Hasil penelitian yang relevan yaitu Akamaludin (2010) tentang Perbandingan Kinerja Guru PNS dan Honorer di SMAN 1 Tambang dikatakan Kinerja guru honorer di SMAN 1 Tambang Kabupaten Kampar tergolong sedang dengan perolehan skor rata-rata 2,58. dan tidak ada perbedaan yang signifikan antara kinerja guru pegawai negeri sipil dan kinerja guru honorer di SMAN 1 Tambang Kabupaten Kampar. Hal ini dibuktikan dengan to $=1,274$ yang lebih kecil dari ttabel baik pada taraf signifikan 5\% maupun pada taraf signifikan $1 \%(2,02$ $>1,274<2,72$ ).

Penelitian yang lain dilakukan Safitria Maya (2016) tentang Perbedaan Kinerja Guru Berdasarkan Status Kepegawaian PNS dan Non PNS di SMA Negeri Se Kabupaten Rembang. disampaikan hasil perhitungan kuisioner bahwa rata-rata skor kelompok guru PNS 160,72 dengan sedangkan ratarata pada kelompok guru non PNS diperoleh 159,57 dengan 105,549 . Setelah perhitungan akhir dengan uji-t diperoleh thitung 0,679 dan Harga tersebut dikonsultasikan ke tabel distribusi $\mathrm{t}$ dengan taraf signifikan $5 \%$, dk = diperoleh dan $t$ tabel 0,679. Perhitungan ujit pada penelitian ini tidak memenuhi kriteria penerimaan Ha yaitu 0,679 < 1,651 maka Ho diterima, dan Ha ditolak sehingga tidak terdapat perbedaan kinerja yang signifikan antara guru PNS dan non PNS di SMA Negeri Se-kabupaten Rembang. Sehingga dapat dinyatakan bahwa tidak terdapat perbedaan kinerja antara guru PNS dan non PNS di SMA Negeri Se-kabupaten Rembang.

\section{KESIMPULAN}

Berdasarkan uraian pada bab sebelumnya dapat diambil beberapa kesimpulan sebagai berikut:

Hasil analisi deskriptif menunjukkan bahwa penilaian rerata Kinerja Guru Bimbingan dan Konseling SMP di Sub Rayon 01 Kota Bekasi baik oleh pengawas, kepala sekolah maupun siswa menunjukan 41\% Baik (22 orang ), 30.2\% Cukup (16 orang), 9.4\% Sedang (5 orang

) sedang dan 18.9\% Kurang Baik (10 orang), dengan rerata kinerja Guru Bimbingan dan Konseling SMP di Sub Rayon 01 Cukup (C) dari jumlah 53 Orang

Hasil kinerja Guru Bimbingan dan Konseling oleh Pengawas diperoleh hasil Cukup (63.48) dengan mean 1.32 menunjukkan ada kelemahan pada kinerja nomer (14) yaitu Mengimplementasikan Program Bk yang Komprehensif .(15), Menilai Proses dan hasil kegiatan Bk dan (17). Menguasai konsep dan praksis penelitian dalam BK

Pencapaian Dimensi Tugas Guru Bimbingan dan Konseling SMP Sub Rayon 01 Kota Bekasi sebesar 64.64 ( Cukup):

Hasil analisis komperatif menunjukkan bahwa kinerja Guru Bimbingan dan Konseling yang Kualifikasi Akademik S1BK, lebih baik daripada Guru Bimbingan dan Konseling yang berlatar pendidikan non BK dan dari Hasil uji Mann-Whitney, 
menunnjukkan nilai statistik uji Z yang besar yaitu -4.603 dan nilai signifikan ( 1 tailed) adalah 000 lebih kecil dari 0.050 , sehingga dapat disimpulkan bahwa ada perbedaan yang signifikan antara kinerja Guru Bimbingan dan Konseling yang kualifikasi akademik S1- BK dengan Guru Bimbingan dan Konseling yang kualifikasi akademik S1- Non BK.

Hasil uji Mann-Whitney didapat output Guru Bimbingan dan Konseling status PNS lebih besar daripada Guru Bimbingan dan Konseling yang berstatus non PNS (40.36 lebih besar 18.23). dapat dilihat pada output test statistik, menunnjukkan nilai statistik uji $\mathrm{Z}$ yang besar kecil yaitu -5.105 dan nilai signifikan ( 1 tailed) adalah 000 lebih kecil dari 0.050 , sehingga dapat disimpulkan bahwa ada perbedaan yang signifikan antara kinerja Guru Bimbingan dan Konseling yang berstatus kepegawaian PNS dengan Guru Bimbingan dan Konseling yang bersatus kepegawaian non PNS.

\section{SARAN}

Berdasarkan kesimpulan dapat disarankan sebagai berikut:

1. Bagi Pemerintah kota Bekasi dan Dinas Pendidikan kota Bekasi:

a. Penempatan tugas sebagai Guru Bimbingan dan Konseling sebaiknya mengambil guru yang kualifikasi S1-BK agar guru dalam menjalankan tugasnya secara profesional sesuai berpedoman pada Undang-undang Guru dan Dosen dan Permendikbud yang berlaku.

b. Kegiatan peningkatan Kompeten Guru Bimbingan dan Konseling berbentuk IHT, Workshop, Seminar, MGBK tingkat Kota bukan hanya untuk SMP Negeri tetapi SMP Swasta juga diikut sertakan.

2. Bagi Pengawas dan Kepala Sekolah:

\begin{tabular}{llr} 
a. Kegiatan & \multicolumn{2}{c}{ Pengembangan } \\
keprofesian & Berkelanjutan & (PKB) \\
merupakan & kelanjutan & dari \\
Penilaian & Kinerja Guru & (PKG)
\end{tabular}

menjadi tugas Kepala sekolah dan dalam bimbingan Pengawas Pembinanya, agar terus dilakukan dan dijadikan analisa kesulitan Guru dalam menjalankan tugas mengajar atau layanan Bimbingan dan Konseling segera dapat di atasi, dengan demikian Kinerja Guru dapat ditingkatkan

b. Pengawas dan Kepala Sekolah dalam tugasnya selaku Supervisor Akademik lebih ditingkatkan dan dibuat laporan hasil kerjanya secara berkala, agar terkontrol Peningkatan Mutu Akademik di Satuan Pendidikan yang dibinanya.

c. Secara berkala dilakukan Audit Mutu Pendidikan agar sekolah tidak lepas dari kendali dan aturan baik dari Pemerintah Pusat, Propinsi dan Kota Bekasi. Hasil dari audit dijadikan Rencana Tindak Lanjut Pemerintah Kota Bekasi dalam menyusun RKJM ( Rencana Kerja Jangka Menengah) dan RKJT( Rencana Kerja Jangka Tahun) Pemerintah Kota Bekasi sq Dinas Pendidikan Kota Bekasi

\section{DAFTAR PUSTAKA}

Corey, G. (2010). Teori dan Praktek Konseling dan Psikoterapi. Bandung: Refika Aditama.

Gibson, J. L. (1996). Organisasi: perilaku, struktur, proses. Jakarta: Binarupa Aksara.

Mangkunegara, A. A. A. P. (2015). Manajemen sumber daya manusia perusahaan. Bandung: Remaja Rosdakarya.

Robbin, S. P. (2003). Perilaku Organisasi. Jakarta: Indeks.

Sinambela, L. (2012). Kinerja Pegawai: Teori, Pengukuran dan Implikasi. Yogyakarta: Grahallmu.

Suharsaputra, U. (2010). Administrasi Pendidikan. Bandung: Refika Aditama. 
Sulistyowati, A. (2012). Problematika

Kompetensi Konselor di SMA Se-

Kabupaten Sleman Yogyakarta.

Yogyakarta: Universitas Negeri

Yogyakarta.

Wahyuningsih, S., \& Wibowo, E. (2011).

Perbedaan Motivasi Kerja Guru PNS

dan Non PNS Dilihat dari

Kepemimpinan, Kepuasan Gaji dan

Lingkungan Kerja. Jurnal Manajemen

Sumberdaya Manusia, 5(2), 89 - 99.

Walantri, L. (2009). Kinerja Guru

Pembimbing Ditinjau dari Latar

Belakang Pendidikan, Tingkat

Pendidikan dan Pengalaman Bekerja di SMP se- Kecamatan Banguntapan

Tahun 2009. Yogyakarta: Universitas

Negeri Yogyakarta. 